\title{
The Application of Flipped Classroom in College English Listening, Viewing and Speaking Class $^{1}$
}

\author{
Wang Jingbo \\ Baicheng Normal University
}

\begin{abstract}
Key Words: Flipped Classroom; College English; Viewing, Listening and Speaking; Application
\end{abstract}
\begin{abstract}
What is flipped classroom Flipped Classroom is also called Inverted Classroom, called FCM for short, which refers to that the teachers fuse the emphases and difficulties of the course with some new knowledge and create relevant teaching videos based on the teaching content; Students use class time to learn the new curriculum autonomously in advance by watching teaching video, realize the transmission process of knowledge; After that, the students should finish their own online testing according to the teaching video, and absorb and internalize the new knowledge, then participate in the interaction, cooperation, sharing and discussion among the students and teachers in class communication with the question in the process of learning, to achieve the complete understanding and grasping of new knowledge, so as to complete the learning process. According to the teaching content, the classroom teachers designs and transcribed teaching video to let the students watch and learn in advance before the class, then the knowledge will transfer from traditional class to time after class, and then students come to the classroom with problems in the study, communicate and discuss with teachers and other classmates, achieving the internalization of knowledge.
\end{abstract}

\section{Origin of the Flipped Classroom concept}

The basic idea and thought of the flipped classroom was first proposed by Silver Weiner of West Point in the early 19th century. He started a new teaching mode, namely teachers distribute the learning materials of new curriculum to students for the preparation before class, and then solve the preview confusion in the classroom through the communication between teachers and students, and make discussion through the establishment of study group, which not only exercises the students' divergent thinking and critical thinking, and improves their communication and cooperation and problem solving skills. In 1991, the famous physics professor at the Harvard University Eric Mazur (Eric Mazur) researched and concluded the study mainly includes the process of knowledge transfer and knowledge internalization, at the same time pointed out that the application of computer in the field of education in the future will be more and more widely, even can replace a part of the teacher's work. This laid the theoretical foundation for the later formation of the flipped classroom concept . In 2000, when three teachers Michael Treglia, Glenn Plattand Maureen Lage from the United States at the university of Miami taught in introductory economics courses, they let the student in the lab or home use multimedia and the Internet to watch teaching video in advance, then went back to the classroom into group and helped each other to finish the homework. This made the teaching mode of flipped classroom begin to take shape, but it has not formed the specific concept of "flipped classroom". In 2004, when Bangladesh Americans Salman Khan for his niece Nadia (Nadia) in the process of maths, he tried to use Windows drawing tools and YAHOO doodle function to explain mathematical concepts, and recorded the process of explain as teaching video. In 2007, he established a non-profit online Khan Academy, namely www.khanacademy.org, uploaded videos for the majority of teachers and students at home and abroad to learn and learn from. This established the prototype for the practice part of the flipped classroom. In 2007, to help truant students with lessons, two chemistry teachers Aaron Sams and Jonathan Berman of "Woodland Park" high school in Colorado in United States used the recording software to record PPT presentation and interpretation process of related courses as videos and uploaded them to the Internet. Surprisingly, students without truancy were very interested in this video, constantly reviewed and reviewed, greatly improving the learning effect. The two teachers were inspired to try to reverse the teaching mode, to let students watch the teaching video at home and discuss the issue 
with other students through interaction in the classroom, which greatly contributed to the improvement of students' academic performance. The application of this kind of teaching mode in the United States has caused wide public concern over quickly, in Minnesota Steele Voight of United States at highland village primary school, Bridges primary school and Clinton dell high school practices the flipping classroom in succession, therefore "forest park" high schools have also become the origin of the flipping classroom teaching practice. At the same time, from the open course ware movement of Massachusetts institute of Technology (MIT), the emergence of micro video of Khan Academy, open class of Yale and TED (Technology, Entertainment, Design) education channel and many other high-quality education video resources, provides the support elements for flipping class, to help its development. Until 2011, at the TED conference, Sahlman Khan issued a keynote speech "let us recreate education video, which immediately triggered a global discussion and concern of the education sector. At the end of 2011, the United States New York Times and Canada Globe and Mail was published articles about flipping classroom, among them, Globe and Mail appraised and elected the flipping classroom as major technological change affecting the classroom teaching for the 2011 Annual. Since then, the educational circles around the world have joined in the practice of "flipping classroom" one after another.

\section{The significance and value of flipped classroom on college English audio-visual teaching} skills

(1) The flipped classroom contributes to improve the students' English listening and speaking

For a long time, there is a big problem in English education in our country. From the teaching concept and curriculum provision to the teaching practice, oral English teaching has always been in a position of a subsidiary. Under the condition that the written test results occupy a decisive position, oral ability of most of the English learners are very weak. The speaking practice time of students oral communication in class is very little, and the students' pronunciation, intonation and language fluency need to increase, so the opportunity for students to speak oral English in class is very necessary. The flipped classroom can solve this problem very well. If teachers can record the related knowledge as video to let the students watch and master before the class, in the limited class time the teachers can have more communication with students, making students have more opportunities to speak English. The biggest change the flipped classroom brought to audio-visual course is that in the past, students are listening to and watching during most of the class time, and teachers will introduce some listening skills during this period to students, then oral practice time is less. Under the new mode, the students can master these skills after class, to listen to see, but can allow students to speak during most of the class time, so as to really improve the students' English listening and speaking ability.

(2) The flipped classroom contributes to play the main role of students in the learning process

"In the flipped classroom, the teacher is no longer just the teaching of the course content, more and more become the mentor and promoter of the learning process; students turn from passive recipients into the main body of learning activities; The teaching organization form turns from the "classroom teaching and listening to the lecture and finishing the homework after class" into a "class self-learning and class collaboration inquiry; The classroom content turns into job completion, coaching and answering questions and discussion and exchanges; The role of technology is to provide a convenient learning resources and interactive tools for self-learning and collaborative inquiry; The evaluation form presents multi level and multi dimension." The flipped classroom uses the new mode of combining online learning and classroom answer questions, to maximum help students complete absorption and internalization of knowledge. The students are no longer passive watching and listening, but according to one's own learning ability to decide to the time and the number of watching teaching video, and then come to the classroom with problems, to communicate with teachers, then class function also gets the effective play and ascension in the process, making up the shortcomings in the traditional teaching mode of play, making the class more effective.

(3) The flipped classroom contributes to promote the optimized allocation of education 
resources

The uneven distribution of educational resources is a problem that has long existed in English education in China, and there is a big difference between regions and between urban and rural areas. As a product of the information age, the flipped classroom crossed the space distance. Through the creation of micro video, with the help of Internet and modern information technology, and the integration of the best quality English education resources, the teachers have created a convenient platform for students to study independently, making up and smoothing its area difference. No matter which school you are in, you are able to enjoy the best quality of elite school education resources, are able to receive the best education, realizing"no difference of knowledge transfer". In the process of reintegration and optimal allocation of educational resources, the education fair has implemented.

\section{The feasibility of applying the flipped classroom model in College English listening and Speaking Course}

(1) The basic elements realizing the flipped classroom are already available in the audio-visual course.

"Flipped classroom contains three basic elements: one is the technical elements, mainly for the micro video; The second is the process elements, mainly for the" "before-in-after class teaching activities; The third is environmental elements, mainly study analysis system with the function of intelligent diagnostic". Its implementation needs the support of school information support environment, which includes both the software system and the hardware system. The software system includes six aspects: the first is the micro video publishing system; The second is the interactive system; The third is the intelligent diagnosis system for students to study; The forth is the remote support and service system; The fifth is statistic system; The sixth is management system. The hardware system includes three aspects: the first is teachers and students must have access to the Internet PC or terminal; the second is the network bandwidth should ensure the stable operation of micro video; the third is that the server must have sufficient capacity and concurrency. College English teaching has been equipped these factors, after they opened in campus network of the national various universities in succession, students can at any time get a lot of English learning resources through autonomous learning center or electronic reading room, and teachers can also share prerecorded video with students for the first time through WeChat, Tencent video or Youku video softwares, then the students can conduct discussion and questions and other learning activities by the network platform.

(2) College English teachers have the ability to realize the flipped classroom

First of all, college English teachers have a relatively high degree and a quick ability to accept new things.Taking Baicheng normal college I works at as an example, it is an ordinary undergraduate course college in Western Jilin Province, with 641 people full-time teachers, 494 teachers with doctor's and master's degree, which accounted for $77 \%$ of the total number of teachers. In terms of the country, college English teachers generally have higher educational background and can quickly accept new things. Secondly, college English teachers has better information technology application ability. The rising popularity of computer, the wide use of Internet and the rapid development of the cloud technology in nowadays society, have made our life into the era of big data, and information technology has penetrated into every field of life, then education also failed to escape the baptism. In order to apply the flipped classroom successfully in College English teaching, both teachers and students should enhance their own information technology literacy and computer application skills. Finally, college English teachers have strong scientific research ability. In order to solve their own problems encountered in teaching, college English teachers adopt the methods of teaching and learning teaching. The teacher is not only the teaching practitioners, and researchers in the teaching. The enhancement and promotion of scientific research ability is the most effective way of self-development.

(3) The learning characteristics of college students are suitable for the teaching mode of flipped classroom 
First of all, college students have a strong self-learning ability, and they can complete the study of micro courses. After the flipped classroom is successfully turned, in order to ensure the quality of classroom teaching activities, that students must be able to effectively and independently study must be as a prerequisite. Only students complete the knowledge absorption in the autonomous learning, interaction between teachers and students in the classroom can be completed in high quality knowledge, transforming knowledge into ability, really put it to use, and gradually get rid of dependence psychology on teachers, then explore new knowledge and from the heart look forward to applying English knowledge to express and exchange proficiently, farewell to the "dumb English" era. Therefore, the intrinsic forced mechanism of the flipped classroom has encouraged students to improve the ability of autonomous learning, which is the ability of a lifetime for students, called "teaching them to fish is inferior to teaching them to fish", coinciding to education informatization today's education curriculum reform have implemented in and the education concept of" lifelong learning ".

Next, college students have a certain ability to communicate in English, to achieve classroom communication basically. Out of the shackles of the university entrance exam, the focus of college students to learn English from test-orientated kind into applied kind. The presentation skill of English has become a very important standard to measure the students' English level, and teachers' tactics from exams sea tactics in high school into classroom oral communication tactics, then most college students have a certain English expression ability, and can realize the exchange with teachers in the classroom.

Finally, the computer application level of college students is generally higher than that of junior high school students.

\section{Conclusion}

The development of information technology triggered the boom of the flipped classroom, but how to design and product the college English audio-visual network curriculum, how to combine with network course and entity class organically, still need to further exploration in practice. The fundamental advantage of the flipped classroom is not the application of technology, but more embodied in the improvement of the overall teaching mode brought by technology development. Only make the further studies from the target, content, presentation mode and evaluation of all parties in the face of college English course, use the advantage of entity class supported by network technology to redesign college English audio-visual course, can better solve the performance problem of college English teaching can be better solved.

\section{Acknowledgements}

This paper is one of the series of research results of JinLin Education and Science Planning Project "The Application of Flipped Classroom in College English Listening,Viewing and Speaking Class", whose number is .GH16367.

\section{References}

[1] McLuhan, M. Understanding Media [M]. New York: New American Library, Inc.

[2] Bergmann, J. \& A Sams. Flipping the Classroom [M]. San Bruno: Tech \& Learning. 2012.

[3] Berrett, Dan. How "Flipping” the Classroom Can Improve the Traditional Lecture [J] The Education Digest, 2012.

[4] Brunsel, E\& M Horejsi. A Flipped Classroom in Action[M]. Washington: The Science Teacher, 2013.

[5] Milman, N. B. The Flipped Classroom Strategy: What is it and How Can it Best be Used? [M] Greenwich: Distance Learning, 2012. 